\title{
Restoration of partial removable dental prosthesis after fabricating of surveyed crowns utilizing electronic surveying: a case report
}

\author{
Byungkwee Min, Daejeon Jun, Hongso Yang, Sangwon Park, Hyunpil Lim, Kwidug Yun*, Chan Park \\ Department of Prosthodontics, School of Dentistry, Chonnam National University, Gwangju, Republic of Korea
}

\begin{abstract}
Adoption of CAD/CAM milling in dentistry has allowed production of more analytic and precise prosthesis. Such precision enables definite path of insertion and undercut to be provided in removable partial denture especially when designing a surveyed crown on an abutment tooth. This case is about the production of surveyed crown with proper path of insertion utilizing CAD/CAM electronic surveying method on a patient with edentulous maxilla. Resulting removable partial denture fit well and showed acceptable stability and retention with no clinical problem. (J Dent Rehabil Appl Sci 2017;33(2):135-42)
\end{abstract}

Key words: partial removable dental prosthesis; metal occlusion; surveyed zirconia crown; electronic surveying

\section{서론}

심미성이 필요한 부위에 국소의치를 위한 지대치로 사 용되는 서베이드 크라운을 제작함에 있어 오랜 시간 금 속도재관(PFM, porcelain fused to metal)이 사용되어 왔 다. 그러나 국소의치의 지대치로 사용하는데 있어 금속 도재관은 환자가 만족할 만한 기능과 심미성을 획득하기 위한 몇 가지 문제점이 과거부터 지적되어 왔다.

첫 번째는 전장된 도재의 파절문제이다. 환자가 금속 구조물을 착탈하면서 전장된 도재 부분에 지속적인 자극 을 주게 되는데, 이러한 반복적인 하중은 피로를 유발하 여 전장된 도재의 파절을 유발할 수 있다. 이렇게 도재부 분이 파절 되었을 경우, 파절 되기 전의 전장관에 맞추어 제작된 국소의치의 유지력과 안정성에 크나큰 문제를 일 으킬 수 있고, 더 나아가 모든 보철물을 재제작해야 되는 상황에 봉착할 수가 있다. ${ }^{1}$

두 번째는 금속 구조물의 심미성 문제이다. 앞서 말한 파절에 저항하기 위해, 레스트 시트를 포함한 여러 구조

*Correspondence to: Kwidug Yun

Full Professor, Department of Prosthodontics, School of Dentistry, Chonnam National University, 33 Yongbong-ro, Buk-gu, Gwangju, 61186 Republic of Korea Tel: +82-62-530-5842, Fax: +82-62-530-5639, E-mail: ykd@chonnam.ac.kr

Received: November 28, 2016/Last Revision: March 9, 2017/Accepted: April 10, 2017
물을 금속으로 제작하게 되는데, 이러한 금속 구조물은 심미적인 문제점을 야기할 수 있다. 심미적인 이유가 국 소의치의 설계에 방해를 주어서는 안되며, 도재전장 금 관은 전장금관과 동일한 원칙으로 제작되어야 한다. ${ }^{2}$ 심 미적으로 우수하면서 파절저항성을 가지는 재료는 이러 한 심미적인 문제점과 기능적인 문제점을 해결 가능하 다. ${ }^{3,4}$

세 번째는 명확한 삽입철거로 설정과 언더컷 설정에 있 어 서베이어를 통한 보철물 제작의 한계성이다. 서베이어 에 의한 삽입철거로와 적절한 언더컷 설정 시 치과의사와 치과기공사의 실수 등으로 인하여 오류가 발생할 수 있 다. 만약 이러한 삽입철거로와 적절한 언더컷 설정을 컴 퓨터로 인한 설계와 가공을 거쳐 정밀하게 부여할 수 있 다면, 보다 균일한 유지력과 통일성있는 삽입철거로를 획득할 수 있을 것이다. 전자 서베잉은 치아 표면을 구성 하고 있는 삼각형 면 형태의 폴리곤이 위를 향하는지 아 래를 향하는지 여부에 따라 최대 풍융부 상하를 나누는 것으로, 최대 풍융부 기준으로 언더컷의 위치와 양을 정

Copyright@ 2017 The Korean Academy of Stomatognathic Function and Occlusion. (c) It is identical to Creative Commons Non-Commercial License. 
확히 얻을 수 있다. ${ }^{5,6}$

근래에 새로운 수복재료로 각광받고 있는 지르코니아 크라운의 경우, 이러한 문제점을 모두 해결할 수 있는 대 안으로 제시되고 있다. 단일 구조 지르코니아의 경우, 수 복물의 강도와 내구성도 우수하여 심미성과 파절저항성 을 모두 만족시킬 수 있다. ${ }^{3,4}$ 과거 단일 구조 지르코니아 는 불투명한 성질로 인하여 심미적인 면에서 불리하였으 나, 투과도와 색조가 개선되어 전치부 수복에도 허용할 수 있는 보철물로 선택되고 있다. ${ }^{7,8}$

본 환자는 상악의 다수 상실치를 가진 51세 남자로 스 텐트 삽입술로 와파린을 복용중이어서 향후 몇 년간 임 플란트 식립이 어려운 환자로 향 후 보철물을 임플란트 로 전환하려는 계획을 가지고 있는 환자였다. 본 증례는 이러한 환자의 요구를 만족시키기 위해 지르코니아를 이 용한 전자 서베잉을 통한 서베이드 크라운을 제작하여 파절저항성과 심미성을 모두 만족시킨 보철물을 제작한 환자이다.

\section{증례보고}

본 증례의 환자는 51세 남환으로 상실치에 대한 보철 을 하고 싶다는 주소로 내원하였다. 감염성 심내막염, 발 작성 심방세동, 대동맥판역류의 병력을 가지고 있었으며, 스텐트 삽입술로 와파린을 복용중이어서 대규모의 골이 식을 동반한 임플란트 식립은 어려운 환자였다. 환자는 임플란트 식립이 어려운 기간동안 국소의치를 사용하고, 추후 임플란트로 전환하기를 희망하였다.

상악의 우측 견치, 우측 제 1 소구치, 우측 제 1 대구치, 좌 측 견치, 좌측 제 1 소구치를 제외한 모든 치아가 상실 되 었으며 잔존 치아 또한 동요도를 보였다. 불량한 상악 악 궁에 비해 하악 악궁의 치아는 양호하였으나, 하악 좌측 제 2 소구치의 경우 교두파절 및 다수 치아에 교모가 관
찰되어 파절 및 교합압에 대한 고려가 필요한 환자였다 (Fig. 1, 2).

본원 내원 시 구치부 상실 부위를 수복하는 이행의치 는 없었으나, 전치부 임시 보철물을 착용 중이었다(Fig. 3). 거리상의 이유로 이행의치 제작을 포함한 최종 보철 물 제작을 본원에서 시행하기를 원하였다. 상악에 잔존 해 있는 치아에 대한 방사선적, 임상적으로 평가하였다. 그 중 상악 우측 제 2 대구치는 2 도의 치아 동요도가 관찰 되었고, 타진에도 통증을 호소하여, 이행의치를 착용기 간 동안 예후 평가하여 최종 수복 시 지대치로서 사용여 부를 결정하기로 하였다(Fig. 4). 하악의 경우, 소수의 치 아에서 치아파절 및 교두마모가 관찰되었으나, 임상적으 로 문제를 일으킬 수준이 아니고 환자가 수복을 원치 않 아서 수복처치 하지 않기로 결정하였다.

현재 환자는 와파린을 복용 중이었으며, 추 후 전신 상 태 호전 시 보철물을 임플란트로 전환하기를 희망하였 다. 이러한 환자의 요구사항은 보철물 제작에 있어 주요 한 고려사항으로 생각되었다. 환자와의 상담 결과, 국소 의치 때 사용되었던 금속 구조물이 추후 임플란트로 전 환 시 전체적인 심미성을 해치는 것에 대해 거부감을 표 현하였다. 이에 추후 국소의치를 위한 금속구조물이 보 이지 않는 모노리틱 지르코니아 크라운으로 서베이드 크 라운을 제작하고, 국소의치를 제작하기로 결정하였다.

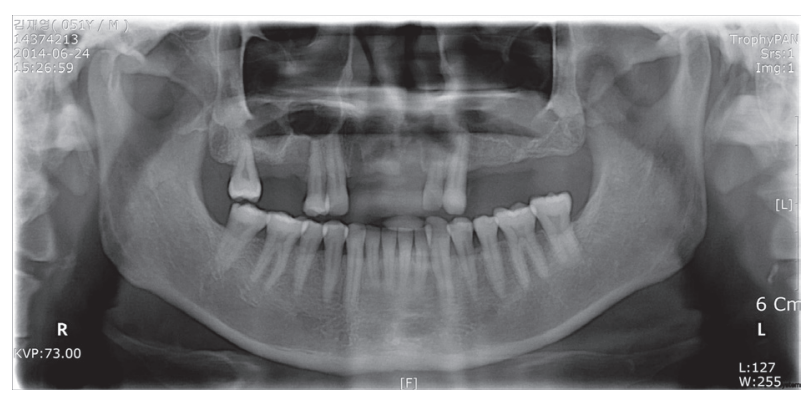

Fig. 1. Initial panographic radiograph.
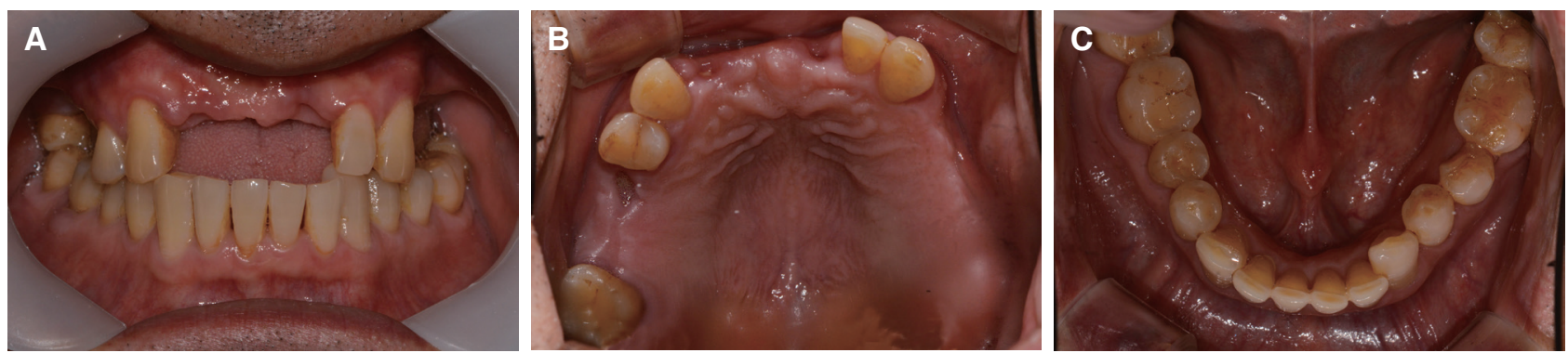

Fig. 2. Initial intraoral photographs. (A) Frontal view, (B) Maxillary occlusal view, (C) Mandibular occlusal view. 


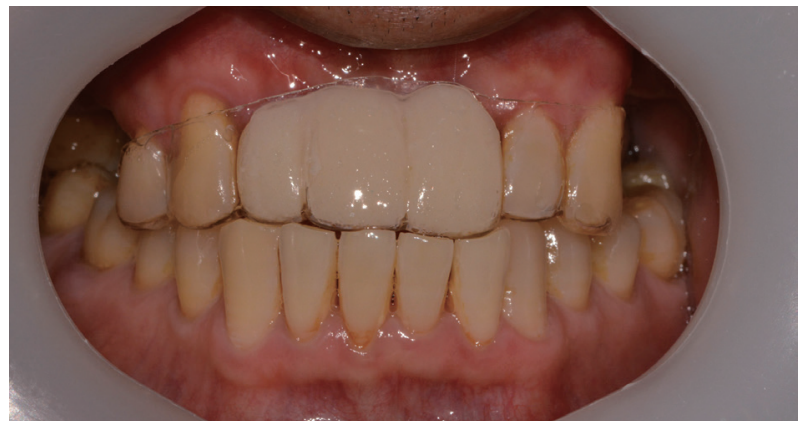

Fig. 3. Temporary prosthesis.

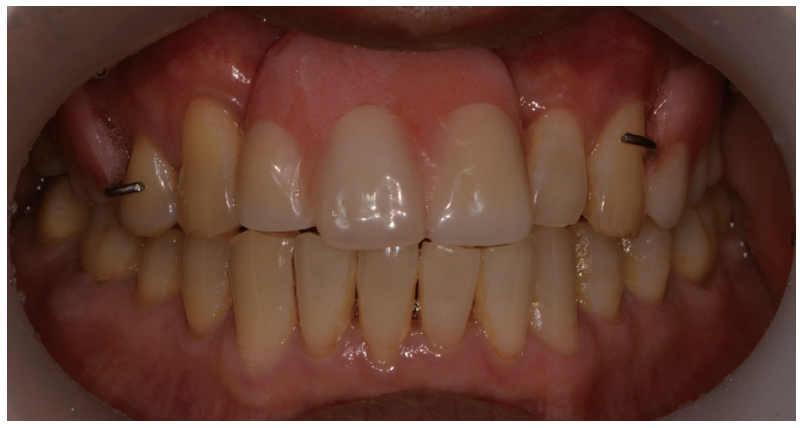

Fig. 4. Interim denture delivery.
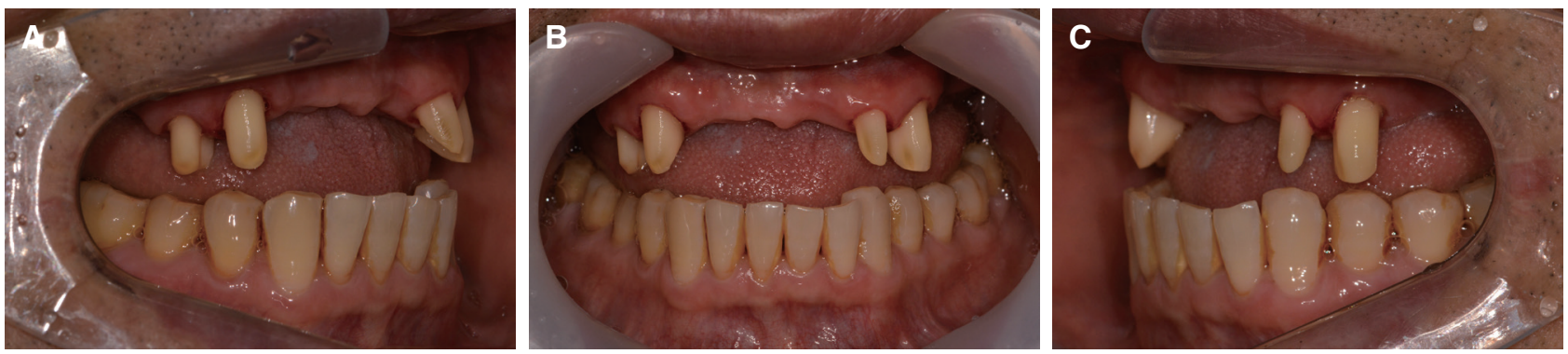

Fig. 5. Intraoral photographs, after preparation. (A) Right lateral view, (B) Frontal view, (C) Left lateralview.

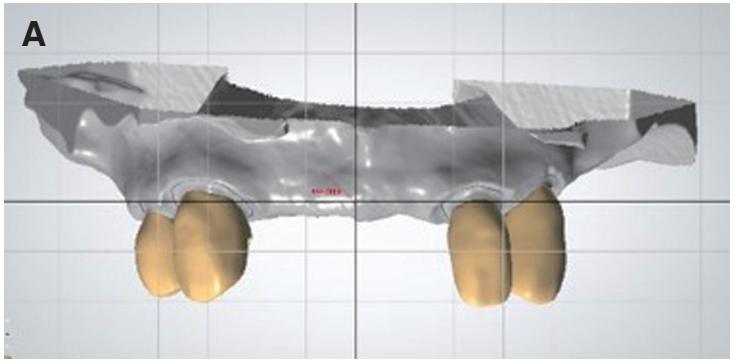

B

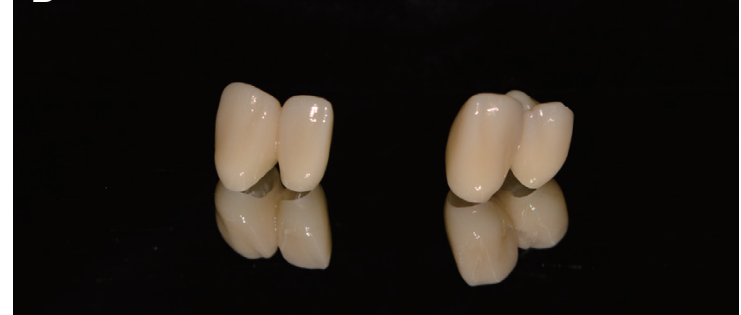

Fig. 6. Surveyed crown design with electronic surveying. (A) Electronic view of abutment teeth after CAD design, (B) Definitive surveyed crown.

상, 하악의 잔존치아 및 구강상태를 이행의치 사용 동 안에 평가해 본 결과, 초기에 예후 불량이 의심되었던 상 악 우측 제 2 대구치는 국소의치의 지대치로 사용하기에 부적절할 것으로 생각되었다. 동요도가 감소하지 않았 고 타진시 통증이 사라지지 않아, 최종적으로 발거하기 로 결정하였다. 남아있는 상악의 지대치를 평가하여, 남 은 지대치를 연결고정하여 지르코니아 서베이드 크라운 을 제작하기로 하였다.

상악의 잔존 지대치의 치아삭제를 시행하였다. $\mathrm{CAD} /$ $\mathrm{CAM}$ 형성에 적절하게 치아 삭제를 시행하였다. 마진 은 deep Chamfer 마진을 부여하였으며, 너무 날카로 운 우각은 다듬어서 치아삭제를 시행하였다(Fig. 5). 이 후 polyvinyl siloxane impression material (Honigum, DMG corp, Hamburg, Germany)을 이용하여 최종인상
을 채득후 작업모형을 제작하였다. 대합치는 알지네이트 를 이용하여 통상의 방식으로 대합모형을 제작하였고, 수직, 수평 교합관계를 채득하였다.

주모형을 스캔하여, 컴퓨터 상에서 적절한 언더컷과 레 스트 등의 보상 및 유지를 위한 의치구조물을 디자인 하 였다. 상악 우측 제 1 소구치는 심미성을 고려하여 금속구 조물이 적게 노출되는 RPI clasp assembly로 디자인하여, I-bar를 위한 10 gauge undercut을 부여하였고, 상악 좌 측 견치는 근심측에 가공선 클래스프로 디자인하여 근심 측에 20 gauge undercut을 부여하였다. 레스트 시트는 좌, 우측 견치에는 설면레스트 시트를 부여하였고, 유도 면은 우측 견치와 좌측 측절치의 근심측과 우측 제 1 소 구치와 좌측 견치의 원심측에 부여하였다(Fig. 6).

쉐이드 지르코니아 블록(CAMeleon Zirconia Block, 
Neobiotech corp., Seoul, Korea)을 이용하여 지르코니 아 크라운을 밀링하여 소결하였다. 모형상에서 의치를 위한 언더컷과 레스트 시트 구조물이 적절하게 형성되었 음을 확인하였다. 완성된 지르코니아 보철물을 환자 구 강 내에 장착하여, 적합도를 확인하였다(Fig. 7).

개인용 맞춤 트레이를 제작하고, 변연형성을 시행하여 상악 인상채득하고, 작업모형을 제작하였다. 제작모형을 서베잉하여 국소의치를 위한 금속구조물을 제작하였다. 금속구조물이 구강내에서의 적합도를 확인하였고, 대합
치와의 교합조정을 시행하였다(Fig. 8). 조정이 완료된 후, 기록상과 교합제를 제작하여 수평적, 수직적 교합관 계를 체득하였다(Fig. 9).

국소의치를 위한 금속구조물에 인공치 식립을 위한 적 절한 수직적 공간이 부족할 것으로 생각되었다(Fig. 10). 인공치를 매우 낮게 배열하는 것과 금속교합면을 제작하 는 방법이 고려되었으나, 상악 대구치부여서 금속의 노 출이 심하지 않을 것으로 생각되어, 환자와 상담하여 금 속교합면을 가지는 국소의치를 제작하였다(Fig. 11). 전
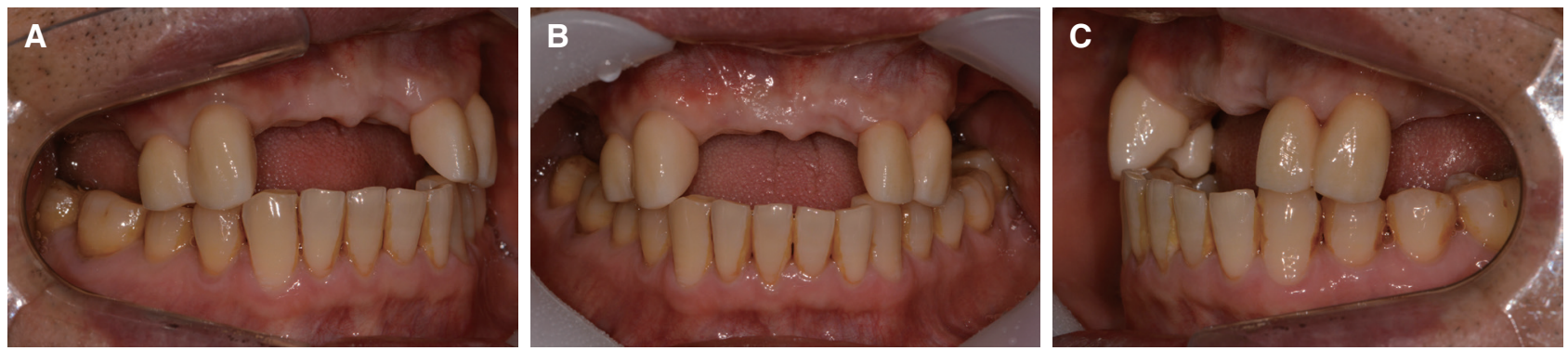

Fig. 7. Surveyed crown delivery. (A) Right lateral view, (B) Frontal view, (C) Left lateral view.
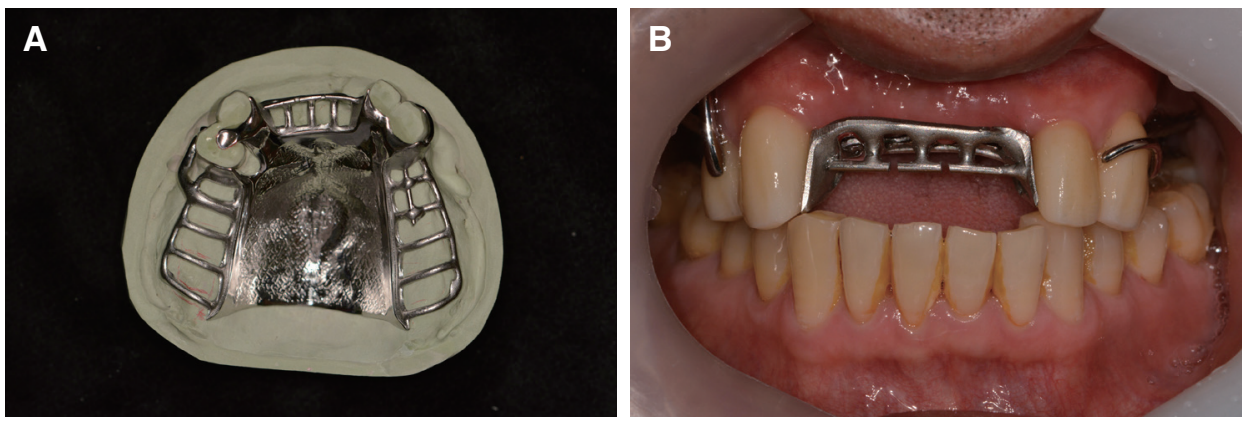

Fig. 8. Metal framework. (A) Metal framework on the master cast, (B) Metal framework try-in.
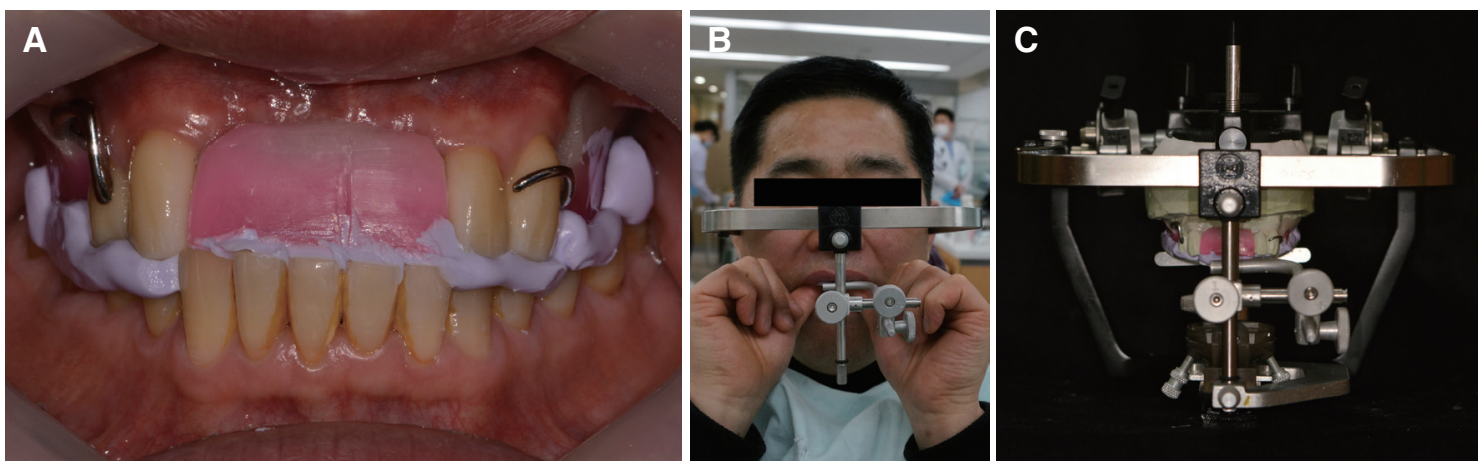

Fig. 9. Maxillormandibular relationship record. (A) VD taking, (B, C) Facebow transfer. 
치부와 소구치부의 치아배열을 하고 납의치를 구강내 시 적하여 교합이 적절한지 확인하고 환자의 심미적인 요구 를 확인하고, 최종의치에 적용하였다(Fig. 12).

완성된 최종 의치를 구강내 장착하고, 중심교합과 측
방운동시 양측성 균형교합을 확인하였다(Fig. 13). 상악 국소의치의 적합도와 유지, 안정성이 우수하고, 심미적으 로 허용할 만한 의치에 대하여 환자가 높은 만족을 표현 하였다.
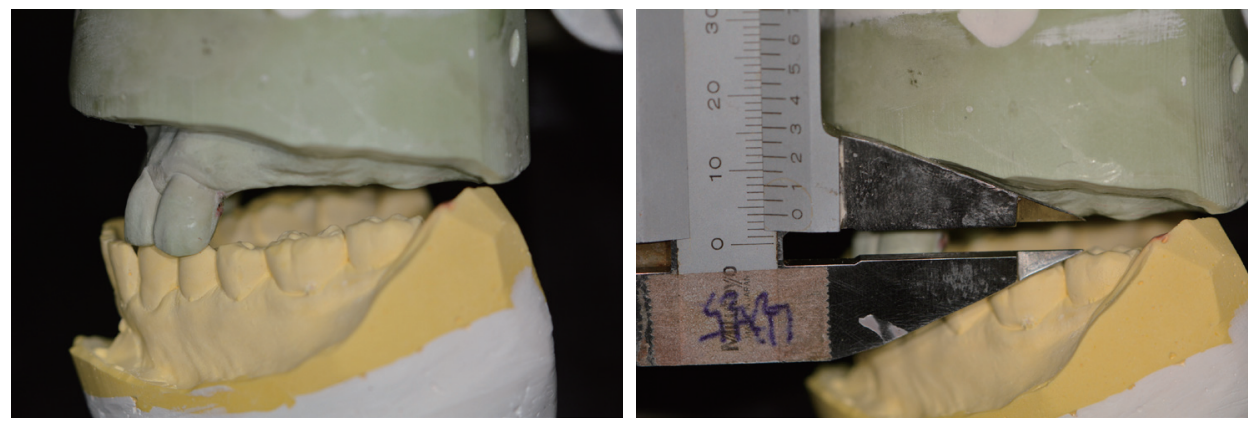

Fig. 10. Insufficient vertical space.
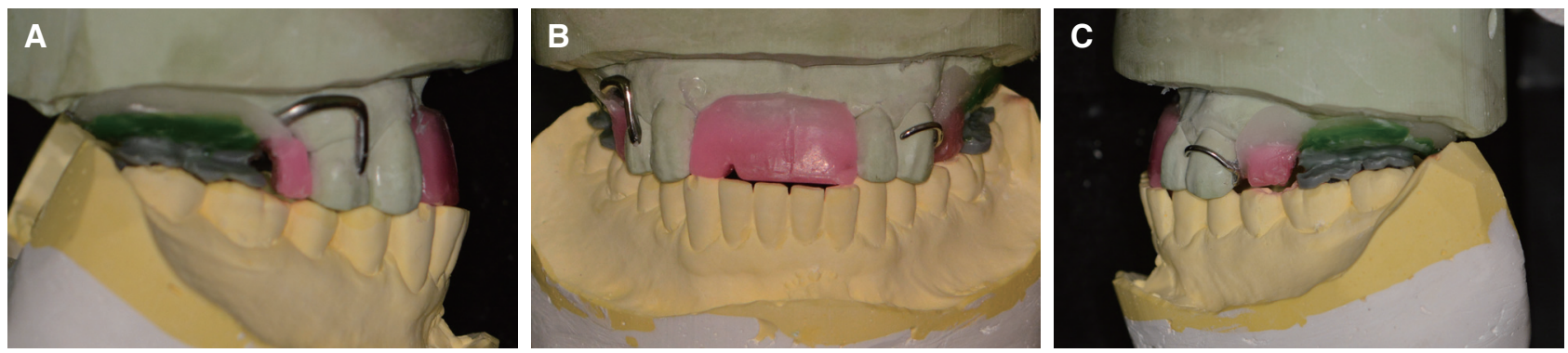

Fig. 11. Wax-up for metal occlusion. (A) Right lateral view, (B) Frontal view, (C) Left lateral view.
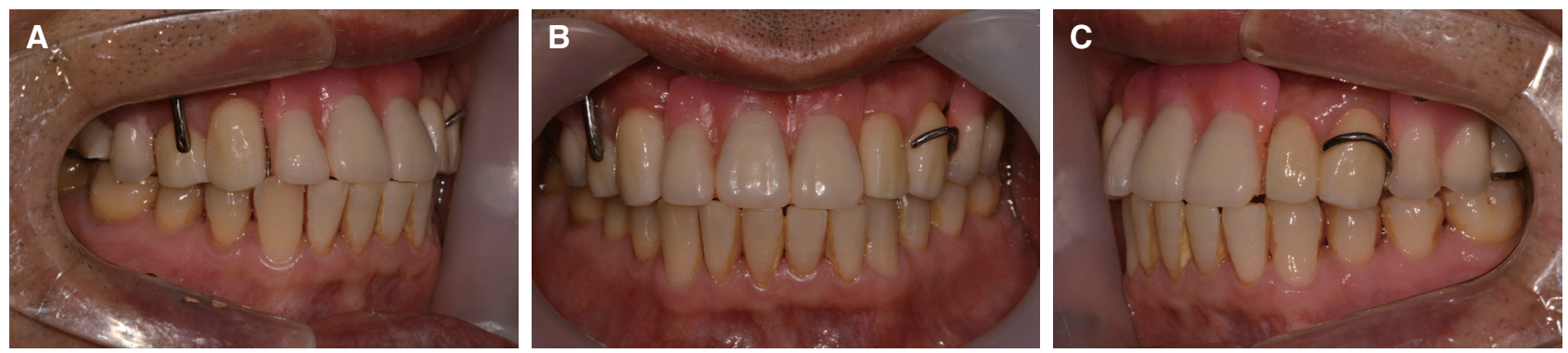

Fig. 12. Wax denture try-in. (A) Right lateral view, (B) Frontal view, (C) Left lateral view.
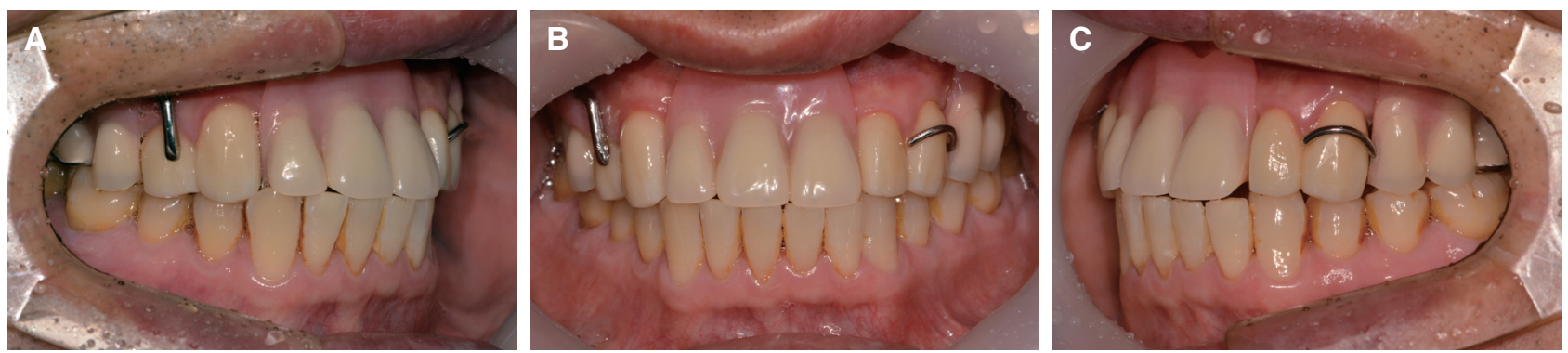

Fig. 13. Definitive denture delivery. (A) Right lateral view, (B) Frontal view, (C) Left lateral view. 


\section{고찰}

도재 전장 하지 않는 모노리틱 지르코니아 크라운은 과거에는 너무 불투명하고 색조가 맞지 않는 느낌의 심 미적인 한계점으로 인하여 전치부에서는 사용이 제한되 었다. 현재는 투명도도 많이 개선되었으며, 색조도 많이 개선된 다양한 블록이 출시되었고, 칼라링을 통해 심미 적으로 허용 가능한 보철물이 제작 가능하다. 이러한 심 미적으로 개선된 지르코니아 블록은 강도적인 면에서 종 래의 지르코니아 블록에 비해 불리함을 보이지만 적절한 두께의 치아 삭제로 허용할 만한 강도를 가진 보철믈을 제작 가능하다.

또한 지르코니아 서베이드 크라운의 제작은 $\mathrm{CAD}$ 장비 로 디자인 되므로, 전자 서베잉으로 설정한 삽입철거로 에 맞는 유도면을 설정할 수 있을 뿐만 아니라, 적절한 언 더컷과 최대풍융부 및 레스트 시트 또한 적절하게 형성 될 수 있다. 전자 서베잉을 통하여 최적으로 디자인되었 기 때문에 치과의사가 느끼는 적합도 및 안착감이 우수 할 뿐만 아니라, 환자가 느끼는 의치의 유지와 안정이 우 수하고, 삽입철거로가 명확하여 환자가 느끼는 장착감이 명확하고 안착감이 우수하다. ${ }^{9}$

본 증례에서 서베이드 크라운은 전자 서베잉을 통해 제작되었지만, $\mathrm{RPD}$ 의 금속 구조물 및 인공치는 종래의 아날로그 방식으로 제작되었다. 금속구조물을 컴퓨터 상 에 디자인하여 소환패턴까지 제작하고 주조를 해야 하 는 것이 한계이지만 플라스틱, 금속 등 분말을 레이저 빔 으로 녹여 조형할 수 있는 SLS (selective laser sintering) 방식이 개발 되고 있다. 이를 사용하면 최종 금속 프레임 워크까지 디지털로 제작 가능할 예정이다. 디지털 방식으 로 제작할 경우, 이러한 술자의 오류와 매몰과 소환시의 부피 팽창, 주조 과정 중의 부피 수축에 따른 부 정확성 을 극복할 수 있을 것이다. ${ }^{10,11}$

현재 구강 내 디지털 인상 채득으로는 국소의치를 위 한 금속구조물을 제작하기 어렵다. 국소의치를 위한 금 속구조물을 제작하기 위해서는 전악의 스캔이 필요한데, 스캔하는 부위가 넓어지는 경우 이미지를 중첩하는 과 정 중에 오류가 발생하여 적합성이 떨어진다. 또한 연 조 직의 스캔의 경우 가동성 조직의 인상의 유동성으로 인 하여 인상을 채득하는 데에는 아직 기술적으로 한계점이 명확하다. 현재 시점에서 모든 과정을 디지털 방식으로 제작하는 것은 어렵고, 추후 기술적인 개발로 보완 개발 이 필요할 것으로 생각된다.
결론

전자 서베잉을 통한 서베이드 크라운을 제작하는 경 우, 단일한 삽입철거로를 명확하게 형성할 수 있을 뿐만 아니라 삽입철거로에 맞는 유지, 지지, 안정을 위한 구조 물을 명확하게 디자인 하여 형성 가능하다. 이렇게 제작 된 서베이드 크라운에 맞게 제작된 국소의치의 경우, 우 수한 적합도와 명확한 장착감을 보여주었다. 현재 정기 적인 검진에서 환자는 기능적, 심미적으로도 만족하고 있 다. 추후 지속적인 검진과 유지 관리를 통해 장기적인 결 과에 대한 평가가 필요할 것으로 생각된다.

\section{ORCID}

Byungkwee Min http://orcid.org/0000-0003-27562284

Daejeon Jun http://orcid.org/0000-0001-6991-0262

Hongso Yang http://orcid.org/0000-0002-9138-4817

Sangwon Park http://orcid.org/0000-0002-9376-9104

Hyunpil Lim http://orcid.org/0000-0001-5586-1404

Kwidug Yun http://orcid.org/0000-0002-2965-3967

Chan Park http://orcid.org/0000-0001-5729-5127

\section{References}

1. Maroso DJ, Schmidt JR, Blustein R. A preliminary study of wear of porcelain when subjected to functional movements of retentive clasp arms. J Prosthet Dent 1981;45:14-7.

2. Bezzon OL, Mattos MG, Ribeiro RF. Surveying removable partial dentures: the importance of guiding planes and path of insertion for stability. J Prosthet Dent 1997;78:412-8.

3. Tinschert J, Natt G, Mautsch W, Augthun M, Spiekermann H. Fracture resistance of lithium disilicate-, alumina-, and zirconia-based threeunit fixed partial dentures: a laboratory study. Int J Prosthodont 2001;14:231-8.

4. Christel P, Meunier A, Heller M, Torre JP, Peille $\mathrm{CN}$. Mechanical properties and short-term in-vivo evaluation of yttrium-oxide-partially-stabilized zirconia. J Biomed Mater Res 1989;23:45-61.

5. Han J, Wang Y, Lü P. A preliminary report of de- 
signing removable partial denture frameworks using a specifically developed software package. Int J Prosthodont 2010;23:370-5.

6. Eggbeer D, Bibb R, Williams R. The computeraided design and rapid prototyping fabrication of removable partial denture frameworks. Proc Inst Mech Eng H 2005;219:195-202.

7. Miyazaki T, Nakamura T, Matsumura H, Ban S, Kobayashi T. Current status of zirconia restoration. J Prosthodont Res 2013;57:236-61.

8. Baldissara P, Llukacej A, Ciocca L, Valandro FL, Scotti R. Translucency of zirconia copings made with different CAD/CAM systems. J Prosthet Dent
2010;104:6-12.

9. Williams RJ, Bibb R, Eggbeer D, Collis J. Use of CAD/CAM technology to fabricate a removable partial denture framework. J Prosthet Dent 2006; 96:96-9.

10. Yadroitsev I, Bertrand P, Smurov I. Parametric analysis of the selective laser melting process. Appl Surf Sci 2007;253:8064-9.

11. Hong YS, Park EJ, Kim SK, Koak JY, Heo SJ, Park JM. Surveyed restoration and RPD framework design utilizing electronic surveying. J Korean Acad Prosthodont 2011;49:354-61. 


\section{전자 서베잉을 이용한 서베이드 크라운 제작 후 국소의치 수복: 증례보고}

민병귀, 전대전, 양홍서, 박상원, 임현필, 윤귀덕*, 박 찬

전남대학교 치의학전문대학원 보철학교실

컴퓨터를 이용한 CAD/CAM milling 방식이 치과 분야에도 적용됨에 따라 보다 분석적이고 정밀한 보철물이 제작 가능 하게 되었다. 특히, 국소의치의 지대치로 사용되는 서베이드 크라운을 제작하는데 있어 이러한 디지털 방식의 정밀함은 국소의치의 삽입철거로와 언더컷 등이 정확하게 부여될 수 있게 한다. 본 증례는 상악의 다수 치아 상실을 보이는 환자에 서 $\mathrm{CAD} / \mathrm{CAM}$ 을 이용하여 전자 서베잉을 통해 적절한 삽입철거로를 부여하고 지르코니아 서베이드 크라운을 제작하였 다. 국소의치의 적합도는 우수했으며, 장착 후 안정성과 착탈 시의 유지력 또한 임상에서 적용하는 데에 문제가 없었다.

(구강회복응용과학지 2017;33(2):135-42)

주요어: 국소의치; 메탈교합면; 서베이드 지르코니아 크라운; 전자 서베잉 